\title{
Lumen
}

Selected Proceedings from the Canadian Society for Eighteenth-Century Studies

\section{Renunciation as Tragedy and Triumph in George Granville's Heroick Love}

\section{John Baird}

Volume 23, 2004

URI : https://id.erudit.org/iderudit/1012189ar

DOI : https://doi.org/10.7202/1012189ar

Aller au sommaire du numéro

Éditeur(s)

Canadian Society for Eighteenth-Century Studies / Société canadienne d'étude du dix-huitième siècle

ISSN

1209-3696 (imprimé)

1927-8284 (numérique)

Découvrir la revue

Citer cet article

Baird, J. (2004). Renunciation as Tragedy and Triumph in George Granville's Heroick Love. Lumen, 23, 115-131. https://doi.org/10.7202/1012189ar

Copyright (c) Canadian Society for Eighteenth-Century Studies / Sociéte canadienne d'étude du dix-huitième siècle, 2004
Ce document est protégé par la loi sur le droit d'auteur. L'utilisation des services d'Érudit (y compris la reproduction) est assujettie à sa politique d'utilisation que vous pouvez consulter en ligne.

https://apropos.erudit.org/fr/usagers/politique-dutilisation/ 


\section{Renunciation as Tragedy and Triumph in George Granville's Heroick Love}

'Superlatively wrote; a very good Tragedy, well Acted, and mightily pleas'd the Court and City.' Thus John Downes, in Roscius Anglicanus, recorded the favourable response to the premiere of George Granville's play Heroick Love in January $1698 .{ }^{1}$ Modern historians of Restoration drama have been less appreciative. Allardyce Nicoll, writing in the 1920s, found Granville's plays in general 'noticeable for their chill,' and this one in particular lacking the 'essential element of individuality.' Robert D. Hume's brisk discussion concludes that 'Granville's first concern seems to be with full, clear presentation of character,' but makes little further comment. ${ }^{3}$ More recently, Derek Hughes has written the play off as 'simply a long, sub-Otwayesque moan. ${ }^{\prime 4}$ It is understandable that those who take all Restoration drama for their province should find little time for a tragedy that was more esteemed than performed, but studies of tragedy in the period have even less to say about Granville's play. ${ }^{5}$ This is regrettable. Granville is an interesting liminal figure: on the one hand, the last of the 'Mob of Gentlemen who wrote with Ease, ${ }^{\prime 6}$ on

1 Downes is quoted in William Van Lennep, ed., The London Stage, 1660-1800. Part I, 1660-1700 (Carbondale: Southern Illinois University Press, 1965), p. 490.

2 A History of Restoration Drama 1660-1700, 2nd ed. (Cambridge: Cambridge University Press, 1928), p. 131, 147.

3 The Development of English Drama in the Late Seventeenth Century (Oxford: Clarendon Press, 1976), p. 453-54.

4 English Drama 1660-1700 (Oxford: Clarendon Press, 1996), p. 457.

5 E.g., Bonamy Dobrée, Restoration Tragedy (Oxford: Clarendon Press, 1929); Eric Rothstein, Restoration Tragedy: Form and the Process of Change (Madison: University Wisconsin Press, 1967).

6 Alexander Pope, The First Epistle of the Second Book of Horace, Imitated, line 108 in Alexander Pope, Imitations of Horace, ed. John Butt (Twickenham Edition of the Poems of Alexander Pope), vol. 4 (London: Methuen, 1969): p. 203; see Paulina Kewes, 
the other hand, the proponent in this play of a novel and unusual ideal of female heroism. The circumstances of the play's production are likewise interesting. Its connection with Dryden and the rival theatre companies of the later 1690s gives it interest as a theatrical document, and a measure of political significance. The author reluctantly rewrote the end of the fifth act, and both endings are preserved. As an adaptation of Homer's Iliad, Heroick Love illustrates changing attitudes towards the classical heritage. As a play, it attempts to replace the standard double plot with a single action, just as its language is less hyperbolical than that of the heroic plays of the 1660s and 1670s. It promotes a new concept of love, one that elevates devotion above possession, and it locates tragedy in the clash between the new and the old conceptions of the heroic (self-sacrifice as against self-assertion). It likewise promotes a positive view of women, testifying to the growing importance of women in the culture of the 1690s.

The career of George Granville (1666-1735) was largely shaped by his Jacobite sympathies. ${ }^{7}$ He belonged to an ancient west of England royalist family, whose branches spelled their name variously as Greenville, Grenville, Granville, and Grenfell. Educated at Trinity College, Cambridge, he spent some years in Paris in the early 1680s, presumably to prepare himself for government service. No position was forthcoming, however, and Granville had perforce to retire to the country and wait. Then the revolution of 1688 brought in a new regime, which Granville could not conscientiously serve. He continued to live in the country (though he must have visited London from time to time), developing his literary interests. By the mid-1690s his lyric verse had won him a considerable reputation. ${ }^{8}$ His first play, The She-Gallants (1696), was adapted from a comedy he had seen in Paris a decade earlier. Two years later came Heroick Love: A Tragedy. His adaptation of Shakespeare's Merchant of Venice, entitled The Jew of Venice, was produced in 1701, and he concluded his literary and dramatic career with an opera, The British Enchanters (1706). Henceforth he devoted himself to politics. In the

Authorship and Appropriation: Writing for the Stage in England, 1660-1710 (Oxford: Clarendon Press, 1998), p. 227.

7 See Elizabeth Handasyde, Granville the Polite: The Life of George Granville, 1666-1735 (London: Oxford University Press, 1935). Unfortunately, Granville's life is not very well documented.

8 A reputation sharply dismissed by Samuel Johnson: 'He seems to have had no ambition above the imitation of Waller, of whom he has copied the faults, and very little more' (Lives of the Most Eminent English Poets, 4 vols. [London, 1781], 3: p. 155). 
general election which followed the accession of Queen Anne (a much more acceptable monarch in Granville's eyes than William III) he had won a seat in the House of Commons as M.P. for Fowey in Cornwall. Following the 1710 election he succeeded Robert Walpole as Secretary of War. On January 1,1712, he was ennobled as Baron Lansdowne, one of the twelve new Tory peers whose votes secured the peace treaty of 1713. Imprisoned in the Tower of London in the wake of the 1715 Jacobite rising, he was never charged, until in 1717 he was pardoned. Lansdowne travelled to France in 1720, allegedly for economic reasons, and lived there for nine years, serving for a time as Secretary of State to the Pretender. He returned to England in 1729, took the oaths of allegiance and abjuration, and resumed his seat in the Lords. His last verses proclaimed his change of allegiance, characteristically in a compliment to a lady, Queen Caroline:

Conqu'ring our Hearts, You end the long Dispute,

All, who have Eyes, confess you ABSOLUTE.

To TORY Doctrine, even WHIGS resign,

And in your PERSON, own a RIGHT Divine.

His plays were given occasional revivals during his lifetime and even later; the last was a performance of Heroick Love in $1766 .{ }^{10}$

Granville is now remembered chiefly as the dedicatee of his friend Alexander Pope's poem Windsor Forest (1713) ${ }^{11}$ :

Granville commands: Your Aid O Muses bring!

What Muse for Granville can refuse to sing? (5-6)

In his own time Granville enjoyed a considerable reputation as a 'near favourite of the muses,' in Delarivier Manley's phrase. He was a poet whose graceful lyrics chronicling his feelings for a lady addressed as

9 Genuine Works in Verse and Prose, of the Right Honourable George Granville, Lord Lansdowne, 3 vols. (London, 1736), 3: [p. 263].

10 George Winchester Stone, Jr., ed., The London Stage, 1660-1800. Part Four, 1747-1776 (Carbondale: Southern Illinois University Press, 1962), 2: p. 1158 (a benefit for Mrs. Yates).

11 Alexander Pope, Pastoral Poetry and An Essay on Criticism, ed. E. Audra and Aubrey Williams (Twickenham Edition of the Works of Alexander Pope, vol. 1) (London: Methuen; New Haven: Yale University Press, 1961), p. 148. 
Mira made her 'as well celebrated as Ovid's Corinna, and as well known.' But Manley chiefly emphasizes his works for the theatre:

He has touched the drama with truer art than any of his contemporaries, comes nearer nature and the ancients, unless in his last performance, which met with most applause, however least deserving. But he seemed to know what he did, descending from himself to write to the many, whereas before he wrote to the few. ${ }^{12}$

The 'last performance' was The British Enchanters, which had enjoyed an immensely successful forty-night run at the Haymarket Theatre in 1706. Manley is surely thinking of Heroick Love as the contrasting work 'before,' when Granville wrote 'to the few.'

Granville's literary talents would certainly have prompted him to write, but he might have written less had politics not intervened. After 1688 his family's attachment to the ousted James II reduced the chances of official employment, even had he been willing to accept it. Jacobite sympathies, however, surely contributed to an association that played a significant role in the genesis of Heroick Love. By the later 1690s, Granville was one of a circle of young writers loosely attached to John Dryden (1631-1700), the leading playwright of his generation, who had been dismissed from his offices, including that of Poet Laureate, after the Glorious Revolution of 1688. A passive resister like Dryden, Granville remained loyal to the king in exile, but did not participate in anti-Williamite plots. He was also a generous friend to Dryden's son Charles. ${ }^{13}$

The ties of family, politics, and literary affiliation linking these men are clearly suggested by the ancillary contributions to the first edition of Heroick Love. ${ }^{14}$ These comprise the prologue to the play, written by Henry

12 Delarivier Manley, New Atalantis, ed. Rosalind Ballaster (London: Penguin, 1992), p. 97.

13 They probably first met at Cambridge. There is reason to believe that Granville gave his receipts from the playwright's benefit on the third nights of the runs of his first two plays to Charles (James M. Osborn, John Dryden: Some Biographical Facts and Problems, rev. ed. [Gainesville: University Florida Press, 1965, p. 155]. For details of how this benefit operated in the 1690s, see the introduction by Emmett L. Avery and Arthur H. Scouten to the first volume of The London Stage (cited in note 1 above), p. lxxx-lxxii. Amounts might exceed $£ 100$.

14 Quotations from Granville's play and front matter follow the text of the first edition: Heroick Love: A Tragedy. As it is Acted at the Theatre in Little Lincoln's-Inn-Fields. Written by the Honourable George Granville, Esq; (London, 1698). References to the unpaginated first gathering are by signature and leaf (A1, A1v, etc.). 
St. John (1678-1751); the epilogue, by Bevill Higgons (1670-1735); and the commendatory verses by Dryden himself. St. John, more familiar under his later title of Viscount Bolingbroke, is best remembered as a politician under Queen Anne and a would-be philosopher in disappointed later life, but in his youth he dabbled considerably in polite literature. He had contributed complimentary verses to Dryden's translation of the works of Virgil in $1697 .{ }^{15} \mathrm{~A}$ few years later, it was his encouragement and patronage which enabled John Philips to complete his poem Blenheim on Marlborough's victory in time to provide a suitably qualified Tory panegyric as a counterweight to the Whig Joseph Addison's unambiguously laudatory poem The Campaign. ${ }^{16}$

The epilogue was supplied by Bevill Higgons (1670-1735), Granville's first cousin; their common grandfather was Sir Bevil Grenville (15961643), a redoubtable Royalist. When Higgons's uncle Dennis Grenville followed James II into exile in France, Higgons went too. Like Granville, he contributed poems to the miscellany volume Examen Poeticum published by Jacob Tonson in 1693, to which Dryden was a major contributor; one of Higgons's poems compliments Dryden on his recently published translation of Persius. ${ }^{17}$ Higgons returned to England in 1695. Suspected of complicity in Jacobite plotting, he was arrested but subsequently released. His commendatory verses for the first edition of William Congreve's first play The Old Bachelor (1695) hail Congreve as Dryden's successor, ${ }^{18}$ thus forestalling the ex-Laureate himself, who waited for Congreve's second play before recognizing him as 'lineal to the throne. ${ }^{19}$

In his verses 'To Mr. Granville, on His Excellent Tragedy Call'd Heroick Love,' Dryden alleges that only personal affection restrains him from envying his young rival, imaging their relationship as a contrast between the persistent but ineffectual ambition of William III and the serene eminence of Louis XIV:

15 Edward N. Hooker, Hugh T. Swedenberg, et al., The Works of John Dryden, 20 vols. (Berkeley, Los Angeles, London: University California Press, 1956-2000), 5: p. 61-62. Hereafter Works and subsequent references are to volume and page.

16 John D. Baird, 'Whig and Tory Panegyrics: Addison's The Campaign and Philips's Blenheim Reconsidered,' Lumen 16 (1997): p. 163-77.

17 Examen Poeticum: Being the Third Part of Miscellany Poems (London, 1693), p. 250-52.

18 The Old Batchelor, A Comedy (London, 1693), sig. A4v -A5.

19 'To My Dear Friend Mr. Congreve, on His Comedy Call'd The Double-Dealer,' (1694), p. 44 (Works, 7: p. 10-11). 
Young Princes, Obstinate to win the Prize,

Thô Yearly beaten, Yearly yet they rise:

Old Monarchs thô Successful, still in Doubt,

Catch at a Peace and wisely turn Devout. (sig. A4 ${ }^{\mathrm{v}}$ )

Dryden then laments the decline of the English stage, evidenced by the popularity of 'foreign Monsters' in the theatres; that is, dancers and other attractions imported from the Continent. ${ }^{20}$ He goes on to disparage Christopher Rich's company for its incompetent revivals of some of his plays:

Thus they jog on; still tricking, never thriving;

And Murd'ring Plays, which they miscall Reviving.

Our Sense is Nonsense, thro' their Pipes convey'd;

Scarce can a Poet know the Play he made;

'Tis so disguis'd in Death .... (sig. A4 $\left.{ }^{v}\right)^{21}$

Then, as if recalling that this poem is supposed to be commendatory rather than an airing of grievances, Dryden rather grudgingly changes course to speak of Granville's play and Betterton's production at the Lincoln's Inn Fields theatre:

I say not this of thy successful Scenes,

Where thine was all the Glory, theirs the Gains;

With length of Time, much Judgment, and more Toil,

Not ill they Acted, what they could not spoil .... (sig. A4 $4^{\mathrm{v}}$ )

How well Granville knew Dryden is not clear; his biographer is as silent as are Dryden's on this point. Like St. John, he had contributed commendatory verses to Dryden's translation of Virgil (1697); his were entitled 'To Mr. Dryden, On His Translations.'22 The question is important because of the possible connection between Dryden's literary work and Granville's tragedy. Dryden finished his nine-day revision of his

20 Hume, Development, p. 458-59.

21 On Dryden's involvement in theatrical wars at this period, see James Anderson Winn, John Dryden and His World (New Haven: Yale University Press, 1987), p. 492-93, and on this poem, p. 496.

22 Retitled in Granville's Genuine Works 'To My Friend Mr. John Dryden, On His Several Excellent Translations of the Ancient Poets,' (1: p. 121-22). 
Virgil translation in December $1697,{ }^{23}$ and tells us twice in the Preface to the Fables (1700) that the earliest item in that collection is the translation of the first book of Homer's Iliad, which he 'intended as an Essay to the whole Work. ${ }^{24}$ Heroick Love is based on the first book of the Iliad. Did Dryden's 'essay' in Homeric translation stimulate Granville's imagination? Did Dryden encourage Granville to adapt the Homeric story for the stage? Or was it Granville, already immersed in the first book of the Iliad, who urged Dryden to undertake a complete translation? ${ }^{25}$

The first book of the Iliad opens with the quarrel between Achilles and his commander-in-chief, which forms the central subject of the poem. Agamemnon has custody of a Theban captive named Chryseis. Her father, the priest Chryses, brings gifts and asks for her return. Agamemnon haughtily refuses this attempt at ransom, and Chryses calls upon Apollo to punish this insult to his priest by sending a plague upon the Greeks. After ten days of disastrous illness, Achilles summons a council of the Greek leaders, who learn from the seer Calchas the cause of the plague. Agamemnon finally most reluctantly agrees to give up Chryseis, and sends her home by ship, but insists that Achilles must repair his loss by yielding him his favoured captive, Briseis. Achilles' fury knows no bounds, and while he is compelled to surrender Briseis, he vows to take no further part in the war.

He said, and soon obeying his intent, Patroclus brought Briseis from her Tent;

Then to th' intrusted Messengers resign'd:

She wept, and often cast her Eyes behind;

Forc'd from the Man she lov'd: They led her thence

Along the Shore a Pris'ner to their Prince. (Dryden's trans., 1. 481-86) ${ }^{26}$

And Achilles goes on to ask his mother, the goddess Thetis, to ensure that victory goes to the Trojans so long as he does not participate in the battle; and thus the tragic action of the poem begins to unfold.

23 Works, 6: p. 844.

24 Works, 7: p. 24, 28.

25 Elizabeth Handasyde points out one passage in which Granville seems clearly to be adapting lines from John Ogilby's 1660 translation of the Iliad (Granville the Polite, p. 252). There are no detectable echoes of Dryden's translation. 
Granville's tragic action stops at this point in the Homeric story, but develops very differently. In the poem, the two females at the heart of the quarrel play no part in the action themselves. Chryseis is only a name except for the single line in which she steps aboard the ship that will take her home. Briseis appears only in the brief passage quoted above. In the play, however, Chruseis (Granville's spelling) is the sensitive central figure, and Briseis has a briefer but vital role as her fiery rival. (Granville was writing for the actresses Elizabeth Barry and Anne Bracegirdle, famous for portraying just such contrasted character types.) $)^{27}$ The scenes of Homer's narration are preserved, and while Granville deals freely with his source, he needed to make no major changes in what it provides, because Homer's scenes are dramatic already. His originality lies in adding substantial parts for the two women, silenced pawns in the Homeric text, and in extending the roles of Ulysses and Nestor as managers of the Greek army who have not lost sight of its mission.

In order to compress the length of time represented on stage, Granville abandons the simple linearity of the Iliad. Act I opens with the plague well established, Agamemnon refusing to accept Chryses' gold as ransom for the woman whom he loves, and who loves him, though she fears some disaster impends. Her father will never abandon his demands for her return. Agamemnon is determined never to take gold for the woman he loves:

I scorn this proffer'd Treasure

My Honour's now concern'd to keep my Love,

Lest the Malicious World, that censures Kings

Like common Men, should say of Agamemnon

That like a sordid Slave, he chang'd for Gold

All that his Soul held dear. (p. 13)

Achilles retorts:

But like a sordid Slave to Lusts as vile;

You matter not to sacrifice your Fame,

To brave the Gods with violated Oaths,

To sell your Faith, your Glory, and the Lives

Of Millions, for a Woman. (p. 13)

27 Rothstein, discussing this contrast, unaccountably defines Briseis (Bracegirdle) as a 'chilly coquette' and Chruseis (Barry) as a 'passionate but honourable mother' (p. 144). Chruseis has no children. 
Whereupon Agamemnon orders Briseis to be taken from Achilles' quarters and brought to his pavilion; not, as in Homer, to replace Chryseis/Chruseis in his bed, but so that Achilles can learn what it is like to be deprived of the woman one loves.

In Act II, while Achilles fumes, imagining Agamemnon ravishing a Briseis who may not put up a very determined resistance, Agamemnon is unmoved even by the news that the gods have withdrawn all support for the Greeks. Chruseis, aware of her implacable father's demands and the hostility of Nestor and Ulysses, is anxious:

By Gods abandon'd, and Mankind pursu'd;

All, all, are Foes to your Chruseis now,

Nothing but Love pleads for me. (p. 30)

Agamemnon replies: 'And Love's enough: What Argument so strong?' (p. 30) The answer to that question will not be long delayed.

'Chruseis' anxieties are increased in Act III by the presence in Agamemnon's quarters of Briseis. Just why did he demand her from Achilles? Ulysses suggests various possibilities to Chruseis, trying to loosen her attachment to the leader of the Greeks. He tells Chruseis that Briseis is more beautiful even than she is, and then, Briseis has the advantage of novelty:

Her's are the Odds, by being Unenjoy'd;

Were there but that, $\mathrm{O}$ 'tis a powerful Charm!

Th'Ill-favour'd, and the Ugly, and the Old,

Pass with this Charm, the Charm of being New. (p. 41)

But Chruseis, thus put on her mettle, is stimulated to face this challenge, and has a spirited exchange with Briseis, which further confirms Chruseis in her determination to stand by Agamemnon and defy her rival.

In Act IV, Ulysses and Nestor try to delude Chruseis into departing by telling her that a burst of military music is a salute to Agamemnon on his successful possession of Briseis. (They lie; it betokens the resumption of hostilities, the opening of the battle in which Patroclus will be killed while Achilles sulks in his tent.) Chruseis decides to confront Agamemnon with his infidelity. In fact he has not betrayed her, and Briseis demands to be allowed to return to Achilles, the only man she loves. Finding them together, Chruseis denounces Agamemnon for inconstancy, and when he assures her that he cares nothing for Briseis, Briseis refuses to confirm that he has never spoken of love to her, because her scorn for him would be pointless if he did not care for her. Chruseis and 
Briseis leave the bewildered Agamemnon blaming Ulysses for causing this misunderstanding, and finally pressing him to find Chruseis and set matters straight.

The last act opens with Briseis' return to Achilles, who naturally supposes she has been unfaithful to him; her rage provokes his passion, and he decides that possession is an immediate good not to be postponed. Meanwhile Chruseis and Agamemnon are reconciled, and he is arming himself to join the battle. Because they are reconciled, Chruseis can now decide that they must part; only if she leaves him will the gods allow him to live and be victorious. If she stays, disaster must ensue.

Not on my Head, but thine, the Vengeance falls,

And for my sake, my Presence is the cause,

Chruseis is the Murderer of Atrides,

The Cup of Pleasure, is the Bowl of Death,

The Gods have mixt it with the deadliest Poyson,

Nor dare I give thee more. (p. 69)

Agamemnon wishes he could give up his command and throne and retire to a rural village with Chruseis, but both understand this is impossible. They embrace, and Agamemnon collapses in a swoon. Chruseis seizes the moment to leave, knowing that by returning to her father she will turn the tide of battle in favour of the Greeks:

All will be well, the Gods are now appeas'd.

Fight for the King, and when the Battles join,

Do you, your duty, as I have done mine. (p. 72)

After she has gone, Agamemnon recovers and rushes to join the battle, seeking only the death that the audience well knows will be deferred until he returns home victorious to Mycenae. ${ }^{28}$ The revised ending gives Ulysses a brief speech summarizing the restoration of the situation while acknowledging the sacrifice that Chruseis has made:

The Ills that Love has done, Love has aton'd.

And Glory calls, to make us full amends...

28 In his preface, Granville explains that after the first night the ending was revised, partly for brevity, partly to accommodate the author's belief that Agamemnon would more likely have 'run after his Mistress, than into the Battel' (sig. A2). 
...And let all Ages, in this Truth agree

Love never gain'd a Nobler Victory. (sig. A2)

It seems clear that Granville is trying, within the general conventions of Restoration theatre, to find an appropriately classical dramatic form to suit his classical subject. Since he mentions Oedipus, the 1679 joint venture by Dryden and Nathaniel Lee, in the preface to Heroick Love, that play may be taken to exemplify what he was trying to improve upon. Dryden prepared the scenario for Oedipus, in which Sophocles' tragedy is considerably modified by intervening treatments by Seneca and Corneille, and by the expectations of audiences of the $1670 \mathrm{~s}^{29}$ There is an important sub-plot involving the treacherous villain Creon's passion for Eurydice, who is devoted to Adrastus, the prince of Argos who has been defeated in battle by Oedipus. Granville has no sub-plot, nor does he create conflict with the A-loves-B-but-B-loves-C device. 'A Tragedy is the Representation of one single particular Action,' he writes in the preface (sig. A3), and defends that Aristotelian principle against those who demand a life of Agamemnon or multiple plot lines. Although the action is set in a military camp in the midst of a war, and both Agamemnon and Achilles are in love with captives, love is not shown in conflict with combatants' loyalties to their nation. Chruseis feels no patriotic reluctance to love Agamemnon, and Chryses' objections to the relationship arise from his daughter's violation of paternal authority and personal morality. It is as an outraged father, not a representative of a conquered nation, that he invokes the plague upon the Greeks. Chruseis is torn not between love and some other obligation, but between two aspects of the same love, that which prompts her to want to be with Agamemnon always, and that which requires her to leave him for his own good. Her renunciation of her lover is not motivated by belated attention to a marriage vow, as are those of the queens Berenice in Dryden's Tyrannick Love (1670) and Almahide in his Conquest of Granada (1671). In both these plays, the queens are released from their vows by the deaths of their detested husbands, and are left looking forward to marrying their lovers after a suitable interval of mourning. Chruseis' renunciation is final, as her absence from the stage at the end of the play emphasizes.

29 See the introduction by Maximillian E. Novak, Works, 13: p. 441-69. Lee wrote Acts II, IV and V (Works, 14: p. 344). 
At the close of his preface, Granville contrasts the indifference of audiences to the 'noble and sublime Thoughts and Expressions of Mr. Dryden in Oedipus,' with their enthusiasm for 'the Rants and Fustian' of Lee. (sig. A4) In his poem, 'An Essay upon Unnatural Flights in Poetry,' first published in 1701, Granville tries to reduce Dryden's culpability for his excesses in the heroic plays of the 1660s and early 1670s:

On the cract Stage the Bedlam Heroes roar'd, And scarce cou'd speak one reasonable word; Dryden himself, to please a frantic Age, Was forc'd to let his judgment stoop to Rage; To a wild Audience he conform'd his voice, Comply'd to Custom, but not err'd thro' choice: Deem then the Peoples, not the Writer's Sin, Almanzor's Rage, and Rants of Maximin .... ${ }^{30}$

And in a note Granville quotes Dryden's own apology for his former 'extravagance' in the dedicatory epistle to The Spanish Friar (1681). ${ }^{31}$ In his tragedy Granville does not altogether avoid 'unnatural flights' when Agamemnon avows his passion, but such passages merely underline the moral conviction of Chruseis' more restrained utterance, and Agamemnon gradually learns to moderate his expressions of emotion.

The Iliad has nothing to say about Chryseis' feelings, though Agamemnon is provoked by Calchas' representations into declaring his love for her:

I love her well: and well her Merits claim

To stand preferr'd before my Grecian Dame:

Not Clytemnestra's self in Beauty's Bloom

More charm'd, or better ply'd the various Loom:

Mine is the Maid: and brought in happy Hour

With ev'ry Houshold-grace adorn'd, to bless my Nuptial Bow'r.

$(1.167-72)^{32}$

30 Joel E. Spingarn, ed., Critical Essays of the Seventeenth Century (3 vols., 1908-9; reprint, Bloomington: Indiana University Press, 1968), 3: p. 294.

31 Works, 14: p. 100-101.

32 Works, 7: p. 272. 
But after this brief eulogy, he promptly decides to restore her to her father for the good of the Greek army. Early in Granville's play, the Homeric Agamemnon's brief speech is replaced by declarations which sound the note of heroic love as heard in Dryden's dramas of the 1660s. First, the pride in possession:

Should Troy escape,

Should Argos too be lost, My Kingdoms all

Laid waste, and Scepters wrested from my Hand,

Whilst I can hold Chruseis, I'm a Gainer,

Within these Arms, I am a Conqueror still. (p. 6)

The familiar paradox of the military victor who is love's captive likewise appears:

... That Agamemnon, King of mightiest Kings

Is Slave to his Chruseis; That the Man

Whom Princes serve, serves thee. (p. 8)

But these declarations are from the start qualified by the speeches of Chruseis to which Agamemnon is responding. She is no ruthlessly self-interested predator, like Lyndaraxa in Dryden's Conquest of Granada, no merciless exploiter of the power of passion. Her love is always expressed as tenderness and dedication to her lover; she dreads only being separated from him, and her reply focuses on Chryses as the father of a daughter who has put love ahead of chastity:

Such Honours might perhaps move other Men,

But Oh! his rigid Virtue, nice, severe,

Allows to Nature nothing. (p. 8)

For Chruseis, the essence of love is not possession but devotion, and the action of Granville's play is designed as a process of education, whereby Agamemnon is brought to recognize and adopt this view himself.

Even as early as the end of Act I, Agamemnon figures his situation not as the traditional dilemma of love versus honour, but a more puzzling three-way struggle:

Love, Piety, and Honour, pull at once

All several ways - Nor know I which to follow. (p. 16) 
In the second act, when told that Agamemnon will likely send her home, Chruseis rebukes him with a contrast of her situation with that of Helen of Troy, and wonders why Agamemnon has less resolve than Paris.

... Has then this Leader of the World in Arms

No Will, no Reason of his own? Must he

Who Governs all, by every one be Govern'd? (p. 23)

Agamemnon, shamed, vows they will never be parted, and tells the gods they can strip him of all his power so long as he can

keep this Blessing. Take, Oh! take

Your Scepters back, and give 'em to my Foes;

Give me but Life, and Love, and my Chruseis,

'Tis all I ask of Heaven. (p. 25)

Following this declaration for mutuality in love, the ensuing hyperbole in Agamemnon's rejection of Calchas' argument that he should renounce Chruseis to save millions from dying, while traditionally 'heroic' at first, leads not to self-assertion but endorsement of the power of love:

And can they better die than for Chruseis?

The World's a worthless Sacrifice for her

More worth than thousand Worlds. Let Chaos come,

Confusion seize on all, whene'er we part;

Int'rest, Ambition, Piety, Renown,

Pity and Reason, I have weigh'd 'em all,

But O how light! When Love is in the Scale. (p. 28)

Nestor is appalled:

This is meer Wildness, Phrenzie, Raving,

Lunaticks talk better Sense. - -If this be Love,

Why then, to Love, is to be Mad, stark Mad. (p. 29)

And from this point on, he and Ulysses try every stratagem they can think of to break the relationship between the lovers, for the sake of the Greek cause. They fail. Despite serious threats and temporary estrangements Chruseis and Agamemnon are not parted until Chruseis, confident that Agamemnon's devotion matches her own, is empowered to sacrifice love itself for the sake of the man she loves.

Chruseis brings Agamemnon to embrace the mutuality of their relationship, but she herself is moving to a yet more elevated concept. She 
defines love and its implications for her in a crucial scene at the centre of the play, in Act III. 'Then what is Love?' she asks. She rejects the idea that it merely quenches desire, for that is mere self-love, 'the brutal Love of Beasts.' Rather, it focuses on the beloved:

Pleas'd only when the thing we love is pleas'd;

Partaking of its Sorrows, seeking its good;

Desirous more to give than to receive;

Willing to part with all, with Fortune, Life;

Chusing all Miseries, satisfy'd, rejoyc'd

With any Ruin that's the means of Safety

To the Man belov'd-Ay - that is Love,

True Love, Heroick Love: 'tis Generous, 'tis Divine. (p. 37)

As the action develops from this point, Chruseis comes to see without qualification that true love demands a sacrifice greater than giving up power or even sharing death; it demands abnegation, giving up love itself. The machinations of Ulysses and Nestor fail because they miss the point. Chruseis is determined to follow the painful path that heroic love - that is, in her understanding, selfless love - requires. At the same time, it is her knowledge of Agamemnon's devotion that enables her to understand that sacrificing herself for her lover must entail not dying for him, but living without him. The most that Ulysses and Nestor can achieve is to cause her to doubt that devotion momentarily. In the final act, as Agamemnon loses consciousness under the pressure of supreme emotion, she firmly announces her decision to leave. To Agamemnon's claim that she cannot love him if she can leave him, Chruseis replies that only Agamemnon can be the sufferer if she remains: 'The Cup of Pleasure, is the Bowl of Death.' Agamemnon cannot, as he desperately proposes, give up his throne for love in a cottage. She tells him:

Your generous Love, has show'd the way to mine,

Fearing to part, you firmly chuse your Ruin,

Fearing your Ruin, I consent to part.

To part, of every evil is the worst,

All other ills you chuse, but I chuse that,

Love prompting you, to perish for my sake,

Prompts me to keep you safe, whate'er it cost;

Empire and Life, and Glory, are your Victims,

The Joys of Life, and Love itself are mine. (p. 68)

Chruseis' conception of heroic love as the sacrifice of love itself marks a substantial change from heroic love as it is exemplified in the plays of 
the 1660s and 1670s. Dryden's title for his version of the Antony and Cleopatra story, All for Love: or, The World Well Lost (1677), conveys that earlier concept of love precisely. ${ }^{33}$ Chruseis understands that, for Agamemnon, the world cannot be well lost, and she sacrifices her own happiness accordingly. In choosing to rewrite the crucial opening episode of the Iliad, a story of possessive passion among warriors, Granville highlights his revisionist conception of heroism and love. He turns Homer's account as it were inside-out, by giving full humanity and narrative prominence to the female characters who are merely desirable objects in the Iliad, especially to his protagonist Chruseis. But he does not place a female character at the centre of his drama to exploit her potentiality for pathos, as Dryden does with Cressida in his Troilus and Cressida (1679), or as Nicholas Rowe would do five years later with Calista in The Fair Penitent (1703), but to show her as morally and psychologically strong. The contrast between the swooning Agamemnon and the collected Chruseis makes the point visually. She does not die, but walks away from the action, something as hard to do for a lover as for a warrior. Granville's play subordinates warfare and the virtues of a military aristocracy to a conception of love that is hostile to self-assertion and the trope of love as conquest, and that it finds its supreme expression, not in possession, but in renunciation.

Granville's own antecedents and his Tory politics notwithstanding, his tragedy shows him to be thoroughly responsive to cultural changes moving English society in the 1690s, especially the growing influence of women and the court-sponsored campaign for moral reform. ${ }^{34}$ Both Prologue and Epilogue to the play pay tribute to the ladies in the audience and suggest they will understand it even if others do not. 'Chiefly the softer Sex, he hopes to move,' writes St. John in his Prologue, 'Those tender judges of Heroick Love' (sig. A5), and Higgons, after castigating the critics and the 'Viler Rabble' of the pit, had the speaker of the Epilogue gesture towards the only accredited judges among the audience:

33 And not only in plays: the catastrophe of Milton's Paradise Lost (1667) stems from Eve's reluctance to be parted from Adam and Adam's refusal to contemplate life without Eve.

34 See Tony Claydon's interesting study, William III and the Godly Revolution (Cambridge: Cambridge University Press, 1996), which shows how the campaign began within days of William's arrival in London in December 1688. 
'Tis on that shining Circle we depend,

For you-

[To the Ladies.

Our Poet writes, in gratitude defend:

Of Love and Honour, he a Pattern meant,

And took the bright Ideas, that you lent .... (sig. A6)

Little is known of the play's revival in 1713, save that it had been requested by 'several Ladies of Quality. ${ }^{\prime 35}$ This demonstration of female influence in the theatre is wholly appropriate to a play which presents so positive a view of female character. Granville's tragedy may not evoke much pity or fear, but it is designed to generate respect for its heroine.

\section{JOHN BAIRD}

University of Toronto

35 Emmett L. Avery, ed., The London Stage, Part II, i (Carbondale: Southern Illinois University Press, 1960), p. 297. 